\title{
Perceptions of the Role Played by Aquaculture and the Services It Provides for Territories: Complementarity of Survey Types
}

\author{
Syndhia Mathé1,2,3* , Hélène Rey-Valette ${ }^{4}$ \\ ${ }^{1}$ UMR Innovation, TA C-85/15, 73 rue Jean-François Breton 34398 Montpellier Cedex 5, Montpellier, France \\ ${ }^{2}$ INNOVATION, Univ Montpellier, CIRAD, INRA, Montpellier SupAgro, Montpellier, France \\ ${ }^{3}$ IITA Cameroun, Yaoundé, Cameroun \\ ${ }^{4}$ Centre d'Economie de l'Environnement-Montpellier (CEE-M) and LAMETA, Univ. Montpellier, CNRS, INRA, SupAgro, France \\ Email: *syndhia.mathe@cirad.fr, *m.syndhia@cgiar.org, helene.rey-valette@umontpellier.fr
}

How to cite this paper: Mathé, S. and Rey-Valette, H. (2018) Perceptions of the Role Played by Aquaculture and the Services It Provides for Territories: Complementarity of Survey Types. Open Journal of Ecology, 8, 270-285.

https://doi.org/10.4236/oje.2018.84017

Received: March 7, 2018

Accepted: April 28, 2018

Published: April 30, 2018

Copyright $\odot 2018$ by authors and Scientific Research Publishing Inc. This work is licensed under the Creative Commons Attribution-NonCommercial International License (CC BY-NC 4.0). http://creativecommons.org/licenses/by-nc/4.0/

\section{Open Access}

\begin{abstract}
This article discusses the perception of ecosystem services for French and Brazilian pond fish farming. Its aim is to study the extent to which the industry and its stakeholders are aware of the existence of such services in order to be able to prioritize them with respect to social well-being. This identification phase is seldom discussed. It requires that survey questionnaires be designed so as to improve understanding of these perceptions. The surveys undertaken combined both open questions where the interviewees expressed their perceptions spontaneously and closed questions where they were invited to rank a pre-established list of the relevant services. These surveys involved 133 fish farmers and 93 stakeholders. The results show that perceptions differ by question type, and confirm the significance of the questionnaire design and the importance of combining several kinds of approach.
\end{abstract}

\section{Keywords}

Ecosystem Services, Ponds, Fish Farming, Questionnaire Design, France, Brazil

\section{Introduction}

The publication of the Millennium Ecosystem Assessment [1] was a watershed for environmental policy. It provided a framework to analyze ecosystem changes in terms of impacts on human well-being. Degradations in the environment are now seen as the increasing ecological costs of achieving this well-being. This increases the legitimacy of conservation and restoration policies, as this new ref- 
erence framework offers a positive and ethno-centered approach to environmental protection. It entails a win-win relationship where services appear as common goods or as "the dividends that society receives from natural capital" [2]. This change in the frame of reference requires a reassessment of actors' perceptions of these services in order to adapt public policies and promote collective learning processes towards their protection and/or their development. At an individual level, perceptions are determining factors to understand behavior evolution in the face of new standards for ecosystem preservation [3]. At a collective level, they condition adhesion and trust in the institutional systems responsible for the implementation of these measures.

The ecosystem service approach involves several stages: the identification (associated with their spatialization), the monetization, the privatization, and the marketing of services [4], partially adopted by the Ring et al. [2]. Identification is a key stage which conditions the recognition of the value given to these services and the acceptation of policies. Yet, when compared to the other aspects, it is seldom the subject of research. The aim is to identify the representations and practices of the populations or actors in a sector. According to Balmford et al. [5], this preliminary phase is important to understand the reasons underlying the interest in ecosystem preservation in human societies. Their relative importance must then be analyzed in order to rank services. It is worth emphasizing that such ranking depends on the classifications used [6], and that its relevance also depends on the context.

The objective of this article is, therefore, to discuss the service identification phase and, in particular, to analyze the survey methods used to identify and rank these services according to the perceptions of those concerned in a given territory. From a methodological viewpoint, this requires a study of the survey protocols concerning the choice of interviewees and the types of questionnaire used. The choice and the sampling of respondents must reflect the diversity of viewpoints as a function of socio-economic profiles, geographic localization and the statutes and types of structure on which the stakeholders depend. This diversity conditions the identification of the issues associated with services [7] [8] [9] [10]. Rodriguez et al. (2006) show that it is only by surveying local users that some services depending on cultural practices can be identified. This paper therefore focuses on survey and questionnaire types and, more specifically, on the differences and complementarities between open questions implying spontaneous answers, and closed questions regarding the ranking of a pre-defined list of services. This ranking can be based on multiple methods. The spontaneous answers require textual analyses in order to define categories. Spontaneous answers have the advantage of not being influenced by information provided during the survey. They better reflect actor representations. However, they can be influenced by the media or by social networks, as is the case with socially-amplified hazards [11]. The discussion of survey methods is based on the example of ecosystem service identification in pond aquaculture as part of a research project 
(ANR-STRA-PISCEnLIT) focused on ecological intensification in pond culture in France and Brazil. The inclusion of both French and Brazilian ponds has the advantage of taking into account cultural differences. It also makes it possible to compare two forms of pond fish farming:

1) Multi-trophic systems based on recycling farming effluents and utilizing inputs of low food value, in two sub-regions of Brazil (Chapeco and Itajaï) and,

2) Extensive polyculture systems in France (Lorraine and Brenne) which also entail recreational use (fishing trips, nature observation) in sites with particular protection measures (Natura 2000 or Ramsar sites).

The first part of the paper introduces the methodology used to study perceptions: it is based on a literature review of survey types used in the identification of ecosystem services. The second part presents the fish farmers' and the stakeholders' perceptions in France and in Brazil. The final part discusses the results on the basis of the analysis of the differences observed between spontaneous perceptions and those resulting from ranking.

\section{Materials and Methods}

\subsection{Review of the Literature on the Methods Used to Identify Services}

We made a literature review based on scientific articles related to methods for the identification of ecosystem services. In many instances, the issue of service identification is not addressed. Generally, reference lists of ecosystem services are pre-established by experts. Otherwise, research focuses on the services thought to be determinant in the specific case. Hence, the literature focuses much more on the evaluation of ecosystem services than on their identification. This relative imbalance suggests that there are no methodological problems. Yet, it is generally accepted that "the relevance of evaluations depends on the performance of the conceptual frameworks which underpin them" [12]. The service selection methods are a crucial phase [13]. Here, we will examine the methods used to identify the relevant services. Table 1 shows the types of survey and processing methods used. Apart from the articles written by Fisher et al. [14] on the definition of services, and by Muradian and Kumar [13] on the usefulness of these approaches depending on the decision-making scale, most research focuses on particular fields. Generally, the teams undertaking the surveys are already familiar with these research fields. The MEA reference framework is used with no preliminary information on the notion of ecosystem services so as not to bias perceptions. Very diverse methods are used to collect information. They include focus groups, semi-structured interviews, email surveys, expert workshops, and literature reviews. Apart from email surveys (500 to 700 mails sent), interviews were limited to relatively small samples: between 3 and 12 persons in focus groups, and between 19 and 120 in semi-structured interviews. Almost all the surveys involved service beneficiaries, who may be relevant populations or the stakeholders representing them. The information 
Table 1. Review of the literature on the identification of ecosystem services.

\begin{tabular}{|c|c|c|c|}
\hline Reference & Ecosystem types & Survey types & Analytical method \\
\hline Kaplowitz [17] & $\begin{array}{l}\text { Mangroves } \\
\text { (Mexico) }\end{array}$ & $\begin{array}{l}-12 \text { focus groups (of } 4 \text { to } 7 \text { persons) i.e. } 97 \text { residents ( } 14 \% \text { of households) } \\
-19 \text { individual interviews }\end{array}$ & $\begin{array}{l}\text { Textual analysis and transcription of } \\
\text { individual interviews ( } 500 \text { pages) }\end{array}$ \\
\hline $\begin{array}{l}\text { Kaplowitz and } \\
\text { Hoehn [16] }\end{array}$ & $\begin{array}{l}\text { Mangroves } \\
\text { (Mexico) }\end{array}$ & -Individual interviews & Cross tabulation \\
\hline $\begin{array}{l}\text { Rodríguez et al. } \\
{[18]}\end{array}$ & $\begin{array}{l}\text { "Opuntia } \\
\text { scrubland" (Peru) }\end{array}$ & $\begin{array}{l}\text {-Semi-structured interviews with open and closed questions (113 } \\
\text { households) selected randomly among volunteers } \\
\text {-26 semi-structured complementary interviews (cultural aspects) }\end{array}$ & $\begin{array}{l}\text { Textual analysis and creation of } \\
\text { clusters (Similarity matrix) }\end{array}$ \\
\hline $\begin{array}{l}\text { Lewan and } \\
\text { Söderqvist [3] }\end{array}$ & $\begin{array}{l}\text { Catchment basin } \\
\text { (Sweden) }\end{array}$ & $\begin{array}{l}\text {-Farmers (19) and stakeholders (20) (focus group and questionnaire) } \\
\text {-General public representatives (22) (focus group and questionnaire) } \\
\text {-Farmers (119) random selection (mail questionnaire: 50\% return) }\end{array}$ & $\begin{array}{l}\text { Ranking from } 1 \text { (the most significant) } \\
\text { to } 11 \text {. Frequency of replies for services } \\
\text { ranked } 1 \text { to } 3 \text { by type of respondent }\end{array}$ \\
\hline $\begin{array}{l}\text { Quétier et al. } \\
\text { [19] }\end{array}$ & $\begin{array}{l}\text { Grassland and } \\
\text { landscape } \\
\text { (France) }\end{array}$ & Semi-structured interviews (45) with photographic support & $\begin{array}{l}\text { Textual analysis and principal } \\
\text { component analyses combined with } \\
\text { hierarchical classification }\end{array}$ \\
\hline $\begin{array}{l}\text { Mazur and } \\
\text { Curtis [20] }\end{array}$ & $\begin{array}{l}\text { Aquaculture } \\
\text { (Australia) }\end{array}$ & $\begin{array}{l}\text {-Semi-structured interviews ( } 66 \text { stakeholders) } \\
\text {-Mail questionnaires ( } 1200 \text { with 50\% return ratio) }\end{array}$ & Descriptive statistics \\
\hline $\begin{array}{l}\text { Zendehdel et al. } \\
\text { [21] }\end{array}$ & $\begin{array}{l}\text { Natural park } \\
\text { (Iran) }\end{array}$ & Focus group with individual ranking (31 participants). & $\begin{array}{l}\text { Construction and analyses of preference } \\
\text { matrices based on ranking order and } \\
\text { intensity (stochastic dominance) }\end{array}$ \\
\hline
\end{tabular}

collected was also analyzed in various ways: qualitative analysis (manual or machine-based textual analyses), descriptive statistics (relative frequencies and cross-tabulations), qualitative ranking, and bibliographical analysis. The simplifications and the selections of the services depending on their importance in different contexts meant that between 11 and 16 services were considered. Nearly all the research was inter-disciplinary [15]. This is considered crucial by Muradian and Kumar [13] in order to understand the role played by ecosystems and the intertwining of the notion of ecosystem service with society. This work shows that different methods and tools may often be associated by combining qualitative and quantitative dimensions. Kaplowitz and Hoehn [16] recommend the use of complementary methods. According to them, it leads to a more exhaustive inventory of services. Several authors emphasize the fact that some interviewees are reluctant to rank services, and prefer to see nature as a whole. This view reinforces the need to study the interactions between services which are rarely addressed in the literature. It is also noteworthy that in most research, the researchers undertake the interviews themselves. Finally, the identification of ecosystem services is usually a preliminary stage in their evaluation.

\subsection{Site Characteristics ${ }^{1}$}

\subsubsection{In France}

Brenne and Lorraine are key regions in pond aquaculture, representing $10 \%$ and

${ }^{1}$ Sites were selected in areas where researchers had close contacts with the industry and ranged from "production" systems with low input and output levels (extensive and semi-intensive ponds) to very productive "processing" systems. 
$7 \%$ respectively of national production (FLAC, 2005). These ponds date back to the Middle Ages, more specifically the $\mathrm{X}^{\text {th }}$ century. The main species are the common carp, the roach, the common rudd, the tench, the pike, the perch, the pike-perch, and the noble crayfish. The production is mainly intended for enhancement (70\% in Brenne and $90 \%$ in Lorraine). In both regions, fishing and marketing are carried out by a dozen traders. Many enterprises welcome visitors (fishing trips, fish sales on site, open days, and nature observation). The activity is highly regulated by environmental standards, in particular under the European Water Framework Directive. Many ponds belong to the Regional Nature Parks. Table 2 shows the main characteristics of the sites.

\subsubsection{In Brazil}

Pond fish-farming in the south of Brazil (Santa Catarina State) is a recent activity that has expanded rapidly since the 1990s. Businesses are family-run and use earth ponds. The activity is associated with recycling farming effluents and the utilization of low-food-value inputs. Survey sites were selected in two areas of particular interest: the High Valley of Itajai in the East where the activity is highly structured, and that of Chapeco in the West where the organization is weaker, as it is in the rest of the region. New laws have been implemented in order to professionalize the sector and reduce environmental impacts. They establish permanent preservation zones "APP" (Area de Preservacion Permanente) and require installations to be at least $30 \mathrm{~m}$ from rivers. Training was provided for fish farmers in the Itajai area through an organization (Mavipi) within which all producers adhere to the same environmentally-friendly production method. The output goes either to the Sao Paulo market or for processing. Table 3 shows the main characteristics of the sites.

\subsection{Designing the Questionnaire}

The questionnaire design took into account recommendations made in the

Table 2. Main characteristics of pond fish-farming in France.

\begin{tabular}{lccccc}
\hline & $\begin{array}{c}\text { Water body } \\
\text { surface area (ha) }\end{array}$ & $\begin{array}{c}\text { Pond production } \\
\text { (in tonnes) }\end{array}$ & $\begin{array}{c}\text { Productivity } \\
\text { (in mt/ha/annum) }\end{array}$ & $\begin{array}{c}\text { Turnover } \\
\text { (millions of euros) }\end{array}$ & $\begin{array}{c}\text { Direct } \\
\text { employment }\end{array}$ \\
\hline Brenne & 10,000 & 1200 & 0.15 & 3 & 125 \\
Lorraine & 7000 & 854 & $0.1-0.4$ & 8.4 & 143 \\
\hline
\end{tabular}

$\left.{ }^{*}\right)$ concerns pond production only. In both regions, there are also trout farms. Source: FLAC [22].

Table 3. Main characteristics of pond fish-farming in Brazil.

\begin{tabular}{ccccc}
\hline & $\begin{array}{c}\text { Water body surface } \\
\text { area (ha) }\end{array}$ & Producers & $\begin{array}{c}\text { Yearly } \\
\text { production (in tonnes) }\end{array}$ & $\begin{array}{c}\text { Productivity } \\
\text { (in mt/ha/annum) }\end{array}$ \\
\hline Mavipi & 157 & 242 & 1274 & 12 \\
Chapeco & 349 & 690 & 1099 & 9.5 \\
\hline
\end{tabular}

Source: Pro-mover and ADEMAVIPI [23] and EPAGRI/CEDAP [24]. 
literature (Table 1). It combined open (spontaneous perceptions) ${ }^{2}$ and closed questions (ranking according to a pre-determined scale [25]. The open questions, placed at the beginning of the questionnaire, enabled perceptions to be identified without mentioning the notion of ecosystem services. We took into account the recommendations of Kaplowitz and Hoehn [16] who suggested that in order to not influence the spontaneous nature of open questions; they should precede more technical and quantitative aspects. The interviewees were then asked to rank the 10 services they valued most from a reference list (Table 4$)^{3}$. Unlike open questions, this list suggested services that may not spontaneously spring to mind. As well as the perception of services, the multiple structural and functional features of enterprises were also to be studied. The main challenge was to establish a reference list of the services (Table 4). As generally recommended in the literature, this classification was adapted by the multidisciplinary group of researchers involved in the project using their knowledge and the available literature. This approach partly concerns wetlands because pond

Table 4. List of ecosystem services related to pond fish-farming (France and Brazil).

\begin{tabular}{|c|c|c|c|c|c|}
\hline & France & Brazil & & France & Brazil \\
\hline \multicolumn{6}{|c|}{ Provisioning } \\
\hline Fish/crustacean production & $\mathrm{X}$ & $\mathrm{X}$ & Energy and fuel production & $\mathrm{X}$ & \\
\hline Vegetable production & $\mathrm{X}$ & & Ornamental resources & $\mathrm{X}$ & $\mathrm{X}$ \\
\hline Freshwater reservoir for irrigation & $\mathrm{X}$ & $\mathrm{X}$ & Medical and veterinary resources & $\mathrm{X}$ & \\
\hline Fiber production & $\mathrm{X}$ & & Source of fertilizers for agriculture & $\mathrm{X}$ & \\
\hline \multicolumn{6}{|c|}{ Regulating } \\
\hline Local climate regulation & $\mathrm{X}$ & & Protection against fires/storms/ floods & $\mathrm{X}$ & $\mathrm{X}$ \\
\hline Water regulation & $\mathrm{X}$ & & Extraction and storage of pollutants & $\mathrm{X}$ & $\mathrm{X}$ \\
\hline Relationship with religion, local culture and traditions & $\mathrm{X}$ & & Hunting and fishing & $\mathrm{X}$ & $\mathrm{X}$ \\
\hline Source of inspiration (artistic), sentimental value & $\mathrm{X}$ & & Tourism/ecotourism & $\mathrm{X}$ & $\mathrm{X}$ \\
\hline Acquisition of know-how & $\mathrm{X}$ & & Leisure & $\mathrm{X}$ & $\mathrm{X}$ \\
\hline Raising environmental awareness & $\mathrm{X}$ & $\mathrm{X}$ & Landscape & $\mathrm{X}$ & \\
\hline \multicolumn{6}{|c|}{ Supporting } \\
\hline Plankton production (phytoplankton and zooplankton) & & $\mathrm{X}$ & Participation in natural nutrient cycles & $\mathrm{X}$ & $\mathrm{X}$ \\
\hline Sanctuaries and nesting areas for migratory birds & $\mathrm{X}$ & $\mathrm{X}$ & Soil formation and maintenance & $\mathrm{X}$ & $\mathrm{X}$ \\
\hline Spawning grounds & $\mathrm{X}$ & & Biodiversity preservation & $\mathrm{X}$ & $\mathrm{X}$ \\
\hline Wetland preservation & $\mathrm{X}$ & & & & \\
\hline
\end{tabular}

${ }^{2}$ The questions asked were as follows: In three words, how would you describe your area in terms of a pond area? In three words, how would you qualify pond fish-farming in the area? In your opinion, what do ponds bring to the region? In your opinion, what role(s) did ponds play in the past? ${ }^{3}$ Given the large number of services and to avoid memorization issues, ranking was noted directly by the interviewee in the summary table. The classification and sequence of services is similar to that of the MEA (2005). 
aquaculture contributes to their conservation and prevents the disappearance of landscapes. The list was operationalized according to the specific context of each site. The existence of a service implies that there is a demand or an effective use for it [26]. This operationalization was facilitated by many years' research experience at the study sites and by partnerships between local fish farmers and researchers, in accordance with the recommendations and findings of the literature.

\subsection{Sampling and Circulation of the Questionnaire}

Face-to-face surveys involving fish farmers and stakeholders (institutional actors, value chain representatives and land owners) were undertaken in each area (Table 5). They varied according to the context ${ }^{4}$ and lasted a couple of hours on average. In order to take diversity into account, the fish farmer sample was drawn from a stratified sampling frame. Three variables of stratification were used: practices (extensive, semi-extensive), statute (legal, economic), and activities (production associated with leisure or not). The spatial localization of enterprises was also included as it affects the importance of water regulation services (position within the catchment basin) and cultural services (degree of isolation).

The differences in the sampling ratio can be explained by the diversity in enterprise types by site. This diversity is particularly great in Lorraine where practically every enterprise shows distinct characteristics.

\subsection{Statistical Analyses}

Open questions generated a large number of key words to qualify the services, which were then related to the MEA categories through textual analysis (combinations validated by Wordmapper). It was then possible to evaluate the frequency of citations by category. Two scores were calculated using the data provided by ranking:

Table 5. Structure of surveyed samples.

\begin{tabular}{ccccccc}
\hline & \multicolumn{3}{c}{ France } & \multicolumn{2}{c}{ Brazil } & \\
\cline { 2 - 5 } & \multicolumn{5}{c}{ Total } \\
\cline { 2 - 5 } & Lorraine & Brenne & Chapeco & Itajai & \\
\hline Number of enterprises & 42 & 200 & 690 & 242 & 1174 \\
Diversity in enterprise type & Very high & One type only & Two types & One type only & - \\
Surveyed sample $\left.{ }^{*}\right)$ & 25 & 33 & 50 & 25 & 133 \\
Sampling ratio & $59 \%$ & $17 \%$ & $7 \%$ & $10 \%$ & $11 \%$ \\
Number of stakeholders surveyed & 32 & 27 & & 34 & 93 \\
\hline
\end{tabular}

$\left.{ }^{*}\right)$ As some of the surveyed fish farmers did not wish to participate in the ranking exercise, the number analyzed was slightly lower.

${ }^{4}$ In order to ensure that survey conditions were homogeneous, the questionnaire was translated into Brazilian and then translated back, and was discussed with the Brazilian partners associated with the project. 
1) The frequency of citations with respect to the number of times a service was selected;

2) The score by service category (used to establish typologies).

Table 8 and Table 9 show the frequency or the importance of each service category were produced for both spontaneous perceptions and ranking. Using multivariate analyses, typologies were then developed for each site, each type of population (fish farmers and stakeholders) and each type of approach (spontaneous perception and ranking). In all, fourteen typologies were established. They were the result of Multiple Correspondence Analyses (MCA) in the case of spontaneous perceptions and Principal Component Analysis (PCA) in the case of ranking (score classification). Each analysis was combined with an ascending hierarchical classification analysis to define the classes. The analysis was undertaken using SPAD (version 5.0). It is not possible to develop in detail all the characteristics of the analysis. Table 6 summarizes their statistical quality on the basis of the variance explained by the principal axes.

\section{Results: Main Perception Types Observed}

\section{1. Creation of Archetypes Showing Perception Gradation with Respect to the Diversity of the Services Mentioned}

The typologies revealed a large number of classes (generally 4 classes per typology). These classes corresponded to a perception centered, in most cases, on one service category (provisioning, regulating, cultural, supporting) considered crucial for the individuals belonging to this class and, occasionally, on the combination of two or more categories. An examination of all classes shows numerous recurrences. In order to simplify the analysis, the results were standardized by grouping similar classes and creating archetypes. These archetypes include all of

Table 6. Statistical quality of the typologies based on the percentage of variance explained by the principal axes.

\begin{tabular}{|c|c|c|c|c|}
\hline & \multicolumn{2}{|c|}{ Spontaneous perception MCA } & \multicolumn{2}{|c|}{ Ranking PCA } \\
\hline \multicolumn{5}{|c|}{ France } \\
\hline & Lorraine & Brenne & Lorraine & Brenne \\
\hline Fish farmers & $\begin{array}{c}64 \% \\
(4 \text { axes) }\end{array}$ & $\begin{array}{c}50 \% \\
(5 \text { axes })\end{array}$ & $\begin{array}{c}94 \% \\
\text { (3 axes) }\end{array}$ & $\begin{array}{c}89 \% \\
(3 \text { axes })\end{array}$ \\
\hline Stakeholders & $\begin{array}{c}59 \% \\
(5 \text { axes) }\end{array}$ & $\begin{array}{c}55 \% \\
(5 \text { axes })\end{array}$ & $\begin{array}{c}90 \% \\
\text { (3 axes) }\end{array}$ & $\begin{array}{c}90 \% \\
(3 \mathrm{axes})\end{array}$ \\
\hline \multicolumn{5}{|c|}{ Brazil } \\
\hline & Chapeco & Itajai & Chapeco & Itajai \\
\hline Fish farmers & $\begin{array}{c}54 \% \\
(4 \text { axes) }\end{array}$ & $\begin{array}{c}55 \% \\
\text { (4 axes) }\end{array}$ & $\begin{array}{c}93 \% \\
\text { (3 axes) }\end{array}$ & $\begin{array}{c}91 \% \\
(3 \text { axes })\end{array}$ \\
\hline Stakeholders & \multicolumn{2}{|c|}{$\begin{array}{c}55 \% \\
(4 \text { axes) }\end{array}$} & \multicolumn{2}{|c|}{$\begin{array}{c}89 \% \\
\text { (3 axes) }\end{array}$} \\
\hline
\end{tabular}


the observed classes. It is interesting to contrast productive approaches (the provisioning services) at one extreme with territorial approaches at the other (Table 7).

\section{2. Diversity of Perceptions in the Case of France}

Table 8 summarizes the results for pond fish farming in France using the defined archetypes.

The findings are as follows. Services mentioned spontaneously concentrate on provisioning and wealth/income, in particular for fish farmers and to a lesser extent for stakeholders. The latter tend to mention several service categories, and to emphasize the productive role that ponds played in the past. In both studied

Table 7. Perception types and their characteristics.

\begin{tabular}{|c|c|c|c|}
\hline & \multicolumn{2}{|c|}{ Service categories mentioned in the typologies } & \multirow{2}{*}{$\begin{array}{l}\text { Perception archetype } \\
\text { Production-based }\end{array}$} \\
\hline \multirow{5}{*}{$\begin{array}{l}\text { Archetypes } \\
\text { with } \\
\text { provisioning }\end{array}$} & 1 & Provisioning & \\
\hline & 2 & Provisioning and supporting & Eco production \\
\hline & 3 & $\begin{array}{l}\text { Provisioning and cultural (income and } \\
\text { leisure) }\end{array}$ & Wealth generation \\
\hline & 4 & Provisioning and regulating & Production planning \\
\hline & 5 & Provisioning and two services & Multidimensional production \\
\hline \multirow{4}{*}{$\begin{array}{l}\text { Archetypes } \\
\text { without } \\
\text { provisioning }\end{array}$} & 6 & Supporting & Pro-biodiversity \\
\hline & 7 & Regulating & Planning \\
\hline & 8 & Cultural & Heritage assets (leisure and social) \\
\hline & 9 & $\begin{array}{l}\text { Two services (cultural and regulating or } \\
\text { regulating and supporting) }\end{array}$ & Territorial \\
\hline
\end{tabular}

Table 8. Perceptions of services in France.

\begin{tabular}{|c|c|c|c|c|c|c|c|c|}
\hline \multirow{3}{*}{ Perception basis } & \multicolumn{4}{|c|}{ Spontaneous perception } & \multicolumn{4}{|c|}{ Ranking } \\
\hline & \multicolumn{2}{|c|}{ Fish farmers } & \multicolumn{2}{|c|}{ Stakeholders } & \multicolumn{2}{|c|}{ Fish farmers } & \multicolumn{2}{|c|}{ Stakeholders } \\
\hline & Number & $\%$ & Number & $\%$ & Number & $\%$ & Number & $\%$ \\
\hline Production & 13 & $25 \%$ & 10 & $17 \%$ & 9 & $17 \%$ & 0 & $0 \%$ \\
\hline Eco-production & 0 & $0 \%$ & 0 & $0 \%$ & 7 & $13 \%$ & 0 & $0 \%$ \\
\hline Wealth generation & 16 & $30 \%$ & 0 & $0 \%$ & 0 & $0 \%$ & 8 & $14 \%$ \\
\hline Production planning & 6 & $11 \%$ & 0 & $0 \%$ & 7 & $13 \%$ & 5 & $8 \%$ \\
\hline Multidimensional production & 3 & $6 \%$ & 23 & $39 \%$ & 0 & $0 \%$ & 0 & $0 \%$ \\
\hline Pro-biodiversity & 0 & $0 \%$ & 5 & $8 \%$ & 14 & $26 \%$ & 23 & $39 \%$ \\
\hline Planning & 3 & $6 \%$ & 0 & $0 \%$ & 5 & $9 \%$ & 6 & $10 \%$ \\
\hline $\begin{array}{l}\text { Heritage assets (leisure and } \\
\text { social) }\end{array}$ & 8 & $15 \%$ & 13 & $22 \%$ & 7 & $13 \%$ & 17 & $29 \%$ \\
\hline Territorial & 4 & $8 \%$ & 8 & $14 \%$ & 4 & $8 \%$ & & $0 \%$ \\
\hline Total $(*)$ & 53 & $100 \%$ & 59 & $100 \%$ & 53 & $100 \%$ & 59 & $100 \%$ \\
\hline
\end{tabular}

Source: Authors' surveys, 2011. 
sites, ponds have a very significant cultural role as they are considered to be a part of the local heritage. Furthermore, in the case of Lorraine, they also play a significant recreational role (walking, fishing, and hunting). In the case of ranking, a wider panel of services is mentioned, essentially supporting services and in particular the preservation of biodiversity, wetlands, the role of the areas as sanctuaries and nesting grounds for migratory birds.

\section{3. Diversity of Perceptions in the Case of Brazil}

Table 9 shows the relative importance of archetypes in the case of Brazilian pond fish-farming

In Brazil, fish-farmers spontaneously placed great importance on provisioning services whereas stakeholders showed awareness of the diverse roles played by ponds (cultural and supporting) and emphasized the importance of the heritage role. As in the case of France, the use of ranking gave different results with the recognition of a wider diversity of service categories. In addition to fish production, the services most frequently mentioned were pollution control, phytoplankton production, and the role of water regulation (role of freshwater reservoirs and the replenishment of aquifers). It should be noted that most ponds in this part of Brazil were built by the government to combat drought, following the series of severe droughts in the 1990s.

\subsection{Comparing Results between Spontaneous Perceptions and Ranking}

To facilitate comparisons, archetypes were divided into five main categories ranging from classic productive perceptions to a more territorial dimension.

Table 9. Perceptions of services in Brazil.

\begin{tabular}{|c|c|c|c|c|c|c|c|c|}
\hline \multirow{3}{*}{ Perception basis } & \multicolumn{4}{|c|}{ Spontaneous perception } & \multicolumn{4}{|c|}{ Ranking } \\
\hline & \multicolumn{2}{|c|}{ Fish farmers } & \multicolumn{2}{|c|}{ Stakeholders } & \multicolumn{2}{|c|}{ Fish farmers } & \multicolumn{2}{|c|}{ Stakeholders } \\
\hline & Number & $\%$ & Number & $\%$ & Number & $\%$ & Number & $\%$ \\
\hline Production & 18 & $26 \%$ & 0 & $0 \%$ & 0 & $0 \%$ & 0 & $0 \%$ \\
\hline Eco production & 15 & $21 \%$ & 0 & $0 \%$ & 6 & $9 \%$ & 0 & $0 \%$ \\
\hline Wealth generation & 27 & $39 \%$ & 19 & $56 \%$ & 16 & $23 \%$ & 5 & $0 \%$ \\
\hline Production planning & 0 & $0 \%$ & 0 & $0 \%$ & 0 & $0 \%$ & 0 & $0 \%$ \\
\hline Multidimensional production & 6 & $9 \%$ & 15 & $44 \%$ & 9 & $13 \%$ & 0 & $0 \%$ \\
\hline Pro-biodiversity & 0 & $0 \%$ & 0 & $0 \%$ & 9 & $13 \%$ & 0 & $0 \%$ \\
\hline Planning & 0 & $0 \%$ & 0 & $0 \%$ & 15 & $21 \%$ & 7 & $21 \%$ \\
\hline $\begin{array}{c}\text { Heritage assets } \\
\text { (leisure and social) }\end{array}$ & 4 & $6 \%$ & 0 & $0 \%$ & 0 & $0 \%$ & 14 & $41 \%$ \\
\hline Territorial & 0 & $0 \%$ & 0 & $0 \%$ & 15 & $21 \%$ & 8 & $24 \%$ \\
\hline Total $\left(^{*}\right)$ & 70 & $100 \%$ & 34 & $100 \%$ & 70 & $100 \%$ & 34 & $100 \%$ \\
\hline
\end{tabular}

Source: Authors' surveys, 2011. 
This range corresponds to an increasing awareness of environmental interactions (Table 10).

The aim is to carry out a systematic comparison of the numbers in each of these main categories with respect to spontaneous perceptions and ranking (Table 11).

Figure 1 and Figure 2 compare sub-totals depending on whether the categories mention the provisioning service which is the traditional function of fish farming, or if instead they focus on the heritage and environmental functions. They enable the differences between spontaneous approaches and ranking to be evaluated.

This comparison shows the differences that exist between spontaneous perceptions and ranking. Spontaneous perceptions place heavy emphasis on provisioning services, whilst these are far less popular with interviewees during the ranking process. Conversely, wealth, heritage, and environmental services gain paramount importance in the ranking exercise. The perceptions of fish farmers and stakeholders were found to be similar in both countries.

Table 10. Defining the main categories.

\begin{tabular}{ccc}
\hline Types & Perceptions & Groups of categories \\
\hline A & Focused on production & 1 \\
B & Eco production, production and development, wealth generation & 2,3 and 4 \\
C & Multidimensional & 5 \\
D & Pro-biodiversity, development, pro-biodiversity and wealth, leisure & 6,7 and 8 \\
E & Territorial & 9 \\
\hline
\end{tabular}

Table 11. Numbers by main categories with respect to spontaneous perceptions and ranking.

\begin{tabular}{|c|c|c|c|c|c|c|c|c|}
\hline & & A & B & $\mathrm{C}$ & & $\mathrm{D}$ & $\mathrm{E}$ & \\
\hline & & Production-based & $\begin{array}{l}\text { Eco production, } \\
\text { production and } \\
\text { development, } \\
\text { wealth } \\
\text { generation }\end{array}$ & $\begin{array}{c}\text { Multidimensional } \\
\text { perception }\end{array}$ & $\begin{array}{l}\text { Subtotal with } \\
\text { provisioning }\end{array}$ & $\begin{array}{l}\text { Pro-biodiversity, } \\
\text { development, } \\
\text { pro-biodiversity } \\
\text { and wealth, leisure }\end{array}$ & $\begin{array}{l}\text { Territorial } \\
\text { perception }\end{array}$ & $\begin{array}{l}\text { Subtotal with } \\
\text { provisioning }\end{array}$ \\
\hline & & & & France & & & & \\
\hline Spontaneous & Fish farmers & 13 & 22 & 3 & 38 & 11 & 4 & 15 \\
\hline perception & Stakeholders & 10 & - & 23 & 33 & 18 & 8 & 26 \\
\hline & Fish farmers & 9 & 14 & 0 & 23 & 30 & 0 & 30 \\
\hline & Stakeholders & - & 13 & - & 13 & 46 & - & 46 \\
\hline & & & & Brazil & & & & \\
\hline Spontaneous & Fish farmers & 18 & 42 & 6 & 66 & 4 & 0 & 4 \\
\hline perception & Stakeholders & - & 19 & 15 & 34 & - & - & 0 \\
\hline & Fish farmers & 0 & 22 & 9 & 31 & 26 & 18 & 44 \\
\hline & Stakeholders & - & 5 & - & 5 & 21 & 8 & 29 \\
\hline
\end{tabular}

Source: Authors' surveys, 2011. 


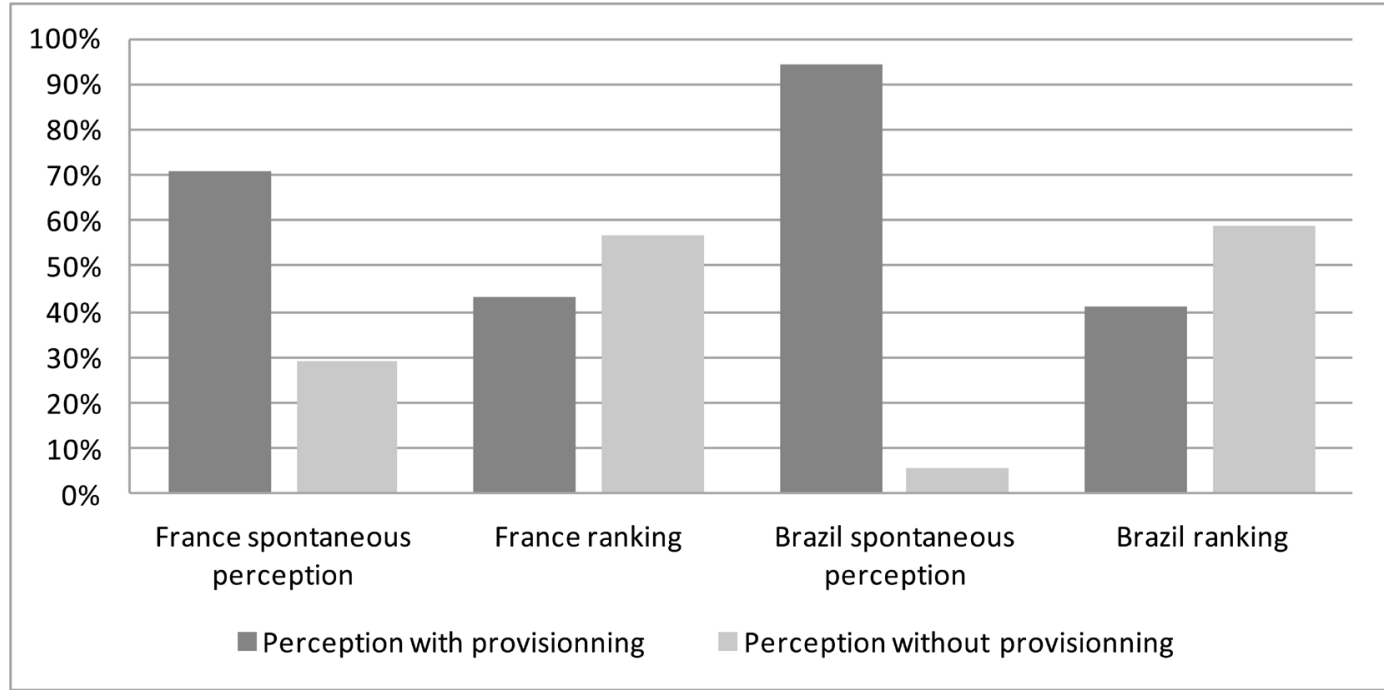

Figure 1. Differences in the perception of services according to the type of survey method used (spontaneous response and ranking) with respect to fish farmers.

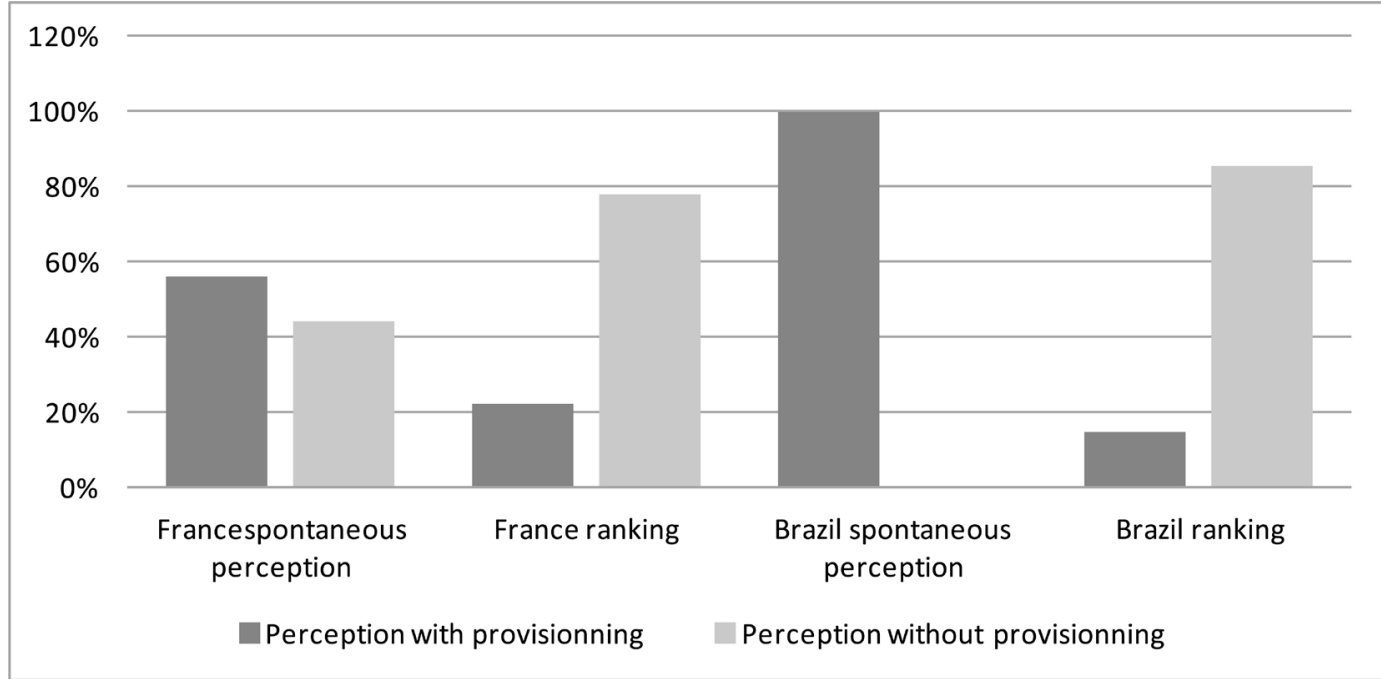

Figure 2. Differences in the perception of services according to the type of survey method used (spontaneous response and ranking) with respect to stakeholders.

\section{Discussion}

The differences observed between spontaneous perceptions and ranking (27\% and 53\% respectively for French and Brazilian fish farmers and 34\% and 85\% for the stakeholders of these two countries) show that using a pre-established list in the ranking process has a suggestive effect on respondents. They then judge some services which had not previously occurred to them to be important. In other words, ranking-based closed questions raise awareness of some services, in particular those involving a greater territorial dimension. This is understandable in that, a priori, such services are outside the realm of the traditional knowledge and practices of fish farmers and stakeholders. This result is common to both Brazil and France even though provisioning services are more important in Bra- 
zil in the case of spontaneous perceptions.

The demonstration of these differences confirms, as was suggested in our literature review, the importance of the questionnaire design during the perception characterization phase. Following Kaplowitz and Hoehn [16], we suggest that the two types of approach be combined in order to develop an exhaustive list of services that makes sense for the actors. When survey constraints prevent this combination, the choice will depend on needs. If it is important to have the widest range of services recognized by actors, ranking is to be preferred. If the objective is to identify the services that are integrated into the local culture and fully appropriated by actors, open questions with spontaneous answers are a better choice. However, in terms of support to decision-making, combining the two types of questions enables the identification of services that are not spontaneously perceived and will require awareness-raising and information actions. The analysis of the differences tends to show the impact of information and knowledge on perceptions. The presentation of an exhaustive list of services in itself gives new information to interviewees. Furthermore, interviews themselves may generate information. Indeed, awareness-raising as interviewers is often required to explain some services during the process. The fact that interviewees become aware of the importance of some environmental or heritage services during the ranking process confirms both the role of training and that of the knowledge of ecological perceptions on perceptions and pro-environmental behavior. It is noteworthy that perceptions which do not include a provisioning service are more common with stakeholders who generally have a higher level of education than fish farmers [27]. This relationship with education is often mentioned in the case of farmers with respect to pro-environmental behavior in general and more particularly in relation to ecosystem services [28]. However, better knowledge may also be generated empirically due to a greater familiarity with ponds. Several forms of knowledge can be distinguished. They depend on proximity, use, experience, or education. Apart from their education level, the origins of fish farmers and stakeholders may also explain the differences observed between them due to their differing degrees of familiarity with ponds and the services that they provide. Fish farmers originate from the area $(76 \%$ in France and 75\% in Brazil) more often than stakeholders (50\% in France and 56\% in Brazil). Moreover, not only do stakeholders have greater education, but also come from very different backgrounds, and have more diverse interests relating to territorial development and public policies.

This set of factors confirms the importance of perception surveys. As shown by Muradian and Kumar [13], they are a key stage in the process of value creation and a crucial preliminary stage for evaluation. These authors stress the fact that identifying insufficiently developed perceptions increases the legitimacy of policies in situations of uncertainty. They therefore emphasize the need for participatory approaches at this level. This identification stage also determines the structure of the ecosystem data and knowledge bases (Ecosystem Services Data- 
base, ESD) which precede the evaluation stage. As noted by Villa et al. [29] these databases are both a collaborative and an educational tool in the recognition of the services and the social acceptation of the relevant conservation measures. In forestry, Agbenyega et al. [30] show that if the perceptions of several categories of users are taken into account, tensions can be avoided when measures are implemented.

\section{Conclusion}

The observed differences by survey type confirm in line with the literature, the usefulness, if not the necessity, of combining spontaneous approaches and ranking. This research also shows that it is useful to study perceptions in order to identify the services that are acknowledged by the actors. This identification stage demonstrates the existence of gaps between the processes and the issues at stake in both 1) public policy and 2) industry and stakeholder perceptions. These differences attest to the importance of information and knowledge with respect to perceptions. Thus, knowledge of perceptions helps to define more appropriate measures and the awareness and information actions that need to be implemented. For example, Bouton and Frederick [31] showed that realistic measures reconciling nesting constraints and tourism could be adopted once perceptions were taken into account. Stakeholder interviews whether in the shape of surveys or focus groups, also play a vital role in raising awareness and facilitate the implementation of public policies concerned with the conservation and value enhancement of these services [30]. However, it must be noted that despite the attention given to designing questionnaires and to the choices of respondents, this work uses a declarative approach and only partially conveys future behavior. This restriction is all the more significant in that this behavior is not only determined by individual factors, but is also heavily influenced by the games that the actors play and the types of governance mechanisms responsible for policy implementation.

\section{Acknowledgements}

This study is part of the PISCENLIT (PISCiculture Ecologiquement InTensive: an approach by ecosystem) research project funded by the French National Research Agency (ANR-09-STRA-08). We gratefully acknowledge the contributions of our project partners. The authors would like to express their sincere gratitude to their Brazilian partners, Jorges Casaca and Sergio Tamassia, and to Pascal Fontaine from the University of Lorraine, who were heavily involved in the surveys, as well as to Nicolas Belhamiti who took part in the statistical analysis.

\section{References}

[1] Assessment, M.E. (2005) Millennium Ecosystem Assessment. Ecosystems and Human Well-Being: Biodiversity Synthesis. World Resources Institute, Washington, DC. 
[2] Ring, I., et al. (2010) Challenges in Framing the Economics of Ecosystems and Biodiversity: The TEEB Initiative. Current Opinion in Environmental Sustainability, 2, 15-26. https://doi.org/10.1016/j.cosust.2010.03.005

[3] Lewan, L. and Söderqvist, T. (2002) Knowledge and Recognition of Ecosystem Services among the General Public in a Drainage Basin in Scania, Southern Sweden. Ecological Economics, 42, 459-467. https://doi.org/10.1016/S0921-8009(02)00127-1

[4] Beaumont, N., et al. (2007) Identification, Definition and Quantification of Goods and Services Provided by Marine Biodiversity: Implications for the Ecosystem Approach. Marine Pollution Bulletin, 54, 253-265. https://doi.org/10.1016/j.marpolbul.2006.12.003

[5] Balmford, A., et al. (2002) Economic Reasons for Conserving wild Nature. Science, 297, 950-995. https://doi.org/10.1126/science.1073947

[6] Dominati, E., Patterson, M. and Mackay, A. (2010) A Framework for Classifying and Quantifying the Natural Capital and Ecosystem Services of Soils. Ecological Economics, 69, 1858-1868. https://doi.org/10.1016/j.ecolecon.2010.05.002

[7] Zhang, X. and Lu, X. (2010) Multiple Criteria Evaluation of Ecosystem Services for the Ruoergai Plateau Marshes in Southwest China. Ecological Economics, 69, 1463-1470. https://doi.org/10.1016/j.ecolecon.2009.05.017

[8] Cocklin, C., Mautner, N. and Dibden, J. (2007) Public Policy, Private Landholders: Perspectives on Policy Mechanisms for Sustainable Land Management. Journal of Environmental Management, 85, 986-998.

https://doi.org/10.1016/j.jenvman.2006.11.009

[9] Hein, L., et al. (2006) Spatial Scales, Stakeholders and the Valuation of Ecosystem Services. Ecological Economics, 57, 209-228.

https://doi.org/10.1016/j.ecolecon.2005.04.005

[10] Vatn, A. (2010) An Institutional Analysis of Payments for Environmental Services. Ecological Economics, 69, 1245-1252. https://doi.org/10.1016/j.ecolecon.2009.11.018

[11] Kasperson, J.X., et al. (2003) 1-The Social Amplification of Risk: Assessing Fifteen Years of Research and Theory. The Social Amplification of Risk, 1, 13-46. https://doi.org/10.1017/CBO9780511550461.002

[12] Salles, J.-M. (2010) Évaluer la biodiversité et les services écosystémiques: Pourquoi, comment et avec quels résultats?/Assess Biodiversity and Ecosystem Services: Why, How and for What Results? Natures Sciences Sociétés, 18, 414-423. https://doi.org/10.1051/nss/2011005

[13] Muradian, R. and Kumar, P. (2009) Payment for Ecosystem Services and Valuation: Challenges and Research Gaps. Payment for Ecosystem Services, 1-16.

[14] Fisher, B., Turner, R.K. and Morling, P. (2009) Defining and Classifying Ecosystem Services for Decision Making. Ecological Economics, 68, 643-653.

https://doi.org/10.1016/j.ecolecon.2008.09.014

[15] Aubin, J., et al. (2017) Implementing Ecological Intensification in Fish Farming: Definition and Principles from Contrasting Experiences. Reviews in Aquaculture, 19 p. https://doi.org/10.1111/raq.12231

[16] Kaplowitz, M.D. and Hoehn, J.P. (2001) Do Focus Groups and Individual Interviews Reveal the Same Information for Natural Resource Valuation? Ecological Economics, 36, 237-247. https://doi.org/10.1016/S0921-8009(00)00226-3

[17] Kaplowitz, M.D. (2000) Identifying Ecosystem Services using Multiple Methods: Lessons from the Mangrove Wetlands of Yucatan, Mexico. Agriculture and Human 
Values, 17, 169-179. https://doi.org/10.1023/A:1007669404425

[18] Rodríguez, L.C., Pascual, U. and Niemeyer, H.M. (2006) Local Identification and Valuation of Ecosystem Goods and Services from Opuntia Scrublands of Ayacucho, Peru. Ecological Economics, 57, 30-44. https://doi.org/10.1016/j.ecolecon.2005.03.022

[19] Quétier, F., et al. (2009) Social Representations of an Alpine Grassland Landscape and Socio-Political Discourses on Rural Development. Regional Environmental Change, 10, 119-130. https://doi.org/10.1007/s10113-009-0099-3

[20] Mazur, N.A. and Curtis, A.L. (2008) Understanding Community Perceptions of Aquaculture: Lessons from Australia. Aquaculture International, 16, 601-621. https://doi.org/10.1007/s10499-008-9171-0

[21] Zendehdel, K., et al. (2008) Qualitative Valuation of Environmental Criteria through a Group Consensus Based on Stochastic Dominance. Ecological Economics, 67, 253-264. https://doi.org/10.1016/j.ecolecon.2008.05.013

[22] FLAC (2005) Analyse du poids socio-économique de la filière aquacole lorraine et évolution. Enquête socio-économique. FLAC, Boimont, 30.

[23] Pro-Mover and ADEMAVIPI (2011) Projecto promovendo piscicultura no alta Vale do Itajai. ADEMAVIPI, Alto Vale do Itajaï.

[24] EPAGRI/CEDAP (2010) Dados da piscicultura de agua doce em Santa Catarina. Epagri, Chapeco.

[25] Duc, N.M. (2008) Farmers' Satisfaction with Aquaculture-A Logistic Model in Vietnam. Ecological Economics, 68, 525-531.

https://doi.org/10.1016/j.ecolecon.2008.05.009

[26] Boyd, J. and Banzhaf, S. (2007) What Are Ecosystem Services? The Need for Standardized Environmental Accounting Units. Ecological Economics, 63, 616-626. https://doi.org/10.1016/j.ecolecon.2007.01.002

[27] Blayac, T., et al. (2014) Perceptions of the Services Provided by Pond Fish Farming in Lorraine (France). Ecological Economics, 108, 115-123.

https://doi.org/10.1016/j.ecolecon.2014.10.007

[28] Weiss, K., Moser, G. and Germann, C. (2006) Perception de l'environnement, conceptions du métier et pratiques culturales des agriculteurs face au développement durable. Revue Européenne de Psychologie Appliquéel European Review of Applied Psychology, 56, 73-81. https://doi.org/10.1016/j.erap.2005.04.003

[29] Villa, F., et al. (2002) Designing an Integrated Knowledge Base to Support Ecosystem Services Valuation. Ecological Economics, 41, 445-456. https://doi.org/10.1016/S0921-8009(02)00093-9

[30] Agbenyega, O., et al. (2009) Application of an Ecosystem Function Framework to Perceptions of Community Woodlands. Land Use Policy, 26, 551-557. https://doi.org/10.1016/j.landusepol.2008.08.011

[31] Bouton, S.N. and Frederick, P.C. (2003) Stakeholders' Perceptions of a Wading Bird Colony as a Community Resource in the Brazilian Pantanal. Conservation Biology, 17, 297-306. https://doi.org/10.1046/j.1523-1739.2003.01148.x 